\title{
Role of Adjuvant Chemoradiotherapy for Abdominal Malignancies
}

\author{
Bengt Glimelius \\ Department of Oncology, Radiology and Clinical Immunology, Uppsala and Radiumhemmet, Karolinska Hospital, \\ Stockholm, Sweden
}

\section{Key Words}

Adjuvant therapy - Chemoradiotherapy - Gastric cancer . Pancreatic cancer $\cdot$ Rectal cancer

\begin{abstract}
The rationale for combining surgery, radiotherapy and chemotherapy is discussed and the clinical results seen with surgery and adjuvant radiochemotherapy in three major abdominal malignancies are reviewed. A systematic approach to the literature was used. In rectal cancer, postoperative radiochemotherapy is an established treatment, although there is weak scientific support for the combined approach. The same clinical gains can also be reached much more easily with preoperative radiotherapy. In gastric cancer, a recent large randomised trial showed improved survival from postoperative radiotherapy. This was not seen in a comparably large trial in pancreatic cancer. The reasons for the different results according to primary tumour site are discussed. It is argued that adequate coverage of all adjacent regional lymph node stations is necessary for an effect on survival.
\end{abstract}

Copyright $\odot 2003$ S. Karger AG, Basel

\section{Introduction}

Abdominal adenocarcinomas are frequently seen, and in the Western world, they constitute about every fourth malignancy. Since prognosis is generally poorer than for other malignancies, approximately every third cancer death is attributed to an abdominal malignancy. The prognosis is particularly poor in those malignancies starting in the pancreas, liver and biliary systems, slightly better in the stomach and more favourable in the colon and rectum. Although improvements in survival have been seen during past decades, they are generally modest at best, and not immediately ascribed to better treatments [1-3].

Surgery is the predominant and most important therapy; however, frequently it is not possible due to an inextirpable primary or the presence of distant spread. Also, in patients where apparently radical surgery has been performed, a substantial number will have recurrence due to microscopic deposits locoregionally or at distant sites. The aim of adjuvant therapy is to kill those deposits to reduce the number of recurrences and thus improve cancer-specific and overall survival.

The outcome after surgery has improved, although this is mainly due to a more favourable postoperative out-

Prof. Bengt Glimelius

Department of Oncology, Radiology and Clinical Immunology, Section of Oncology

University Hospital, Uppsala and Radiumhemmet, Karolinska sjukhuset

S-751 85 Uppsala (Sweden)

Tel. +46 1861155 13, Fax +46 1861155 28, E-Mail bengt.glimelius@onkologi.uu.se
Fax + 41613061234 E-Mail karger@karger.ch Accessible online at: www. karger.com/dsu 
come and a concentration of fewer surgeons, and not so much to better oncologic results. In rectal cancer, it is indisputable that better lateral clearance, generally meaning a total mesorectal excision, together with the recognition that not every general surgeon should operate on rectal cancer, has improved the oncologic results in terms of both fewer local failures and improved survival [4-6]. This has not, however, been tested in randomised trials. In gastric cancer, it is generally recognized that a D1 resection is better than less than D1 (D0), whereas it is still an open question whether a more extensive D2 resection will further improve the results $[7,8]$.

\section{Rationale for Adjuvant Chemotherapy}

Abdominal adenocarcinomas generally show low or very low sensitivity to chemotherapy. Thus, in metastatic disease, cure is impossible, a complete remission is rarely seen $(0-5 \%$ of patients) and a partial remission is seen in between 5 and $50 \%$ of patients, depending upon the primary tumour site. A complete remission, i.e. disappearance of all visible disease, means that at least 1 or 2 logs of cells (out of at least 9 or 10 logs of cells present prior to therapy) have been killed, whereas a partial remission generally means that the number of tumour cells has been reduced by less than 1 log of cells. The remissions, even if complete, are generally short-lived, i.e. median 4-8 months, indicating that most tumour cells are resistant to therapy [9].

Subclinical tumour deposits, responsible for recurrences after a primarily radical surgery, may contain up to about 8 logs of cells, or be about $5 \mathrm{~mm}$ in diameter. It is likely that the tumour cells in a subclinical deposit are more sensitive to cytostatic drugs than those in a visible deposit due to generally better vascularization and a higher number of proliferating cells. Thus, it is possible that not only one or, at the most, two logs of cells are killed by chemotherapy but rather a few logs of cells. Adjuvant chemotherapy in Dukes' $\mathrm{C}$ colon cancer prevents approximately every fourth to third recurrence, i.e. it kills on average 2-3 logs of the up to $8 \operatorname{logs}$ of cells that may be present per deposit after surgery [10]. The situation is analogous to that in moderately sensitive breast cancer, where about every third recurrence is prevented by approximately 6 months of adjuvant chemotherapy $[11,12]$. These average cell-killing effects are, of course, a statistical phenomenon; in some patients with sensitive tumours, more cells can be killed, whereas in others, no tumour cells are killed. However, if the number of cells is high, as in established metastatic disease, chemotherapy will not kill all the cells even if the tumours turn out to be very chemosensitive.

\section{Dose-Response Relationships to Radiotherapy}

Abdominal adenocarcinomas are, like most other epitheloid malignancies, more sensitive to radiotherapy than chemotherapy. Radiotherapy to a dose that is tolerable to a reasonably large volume of the abdominal cavity has the capability to kill up to about $10^{8}-10^{9}$ cells per deposit. The response to radiotherapy of macroscopic disease is generally considered to be steep, whereas the response to radiation of subclinical disease, which may contain from $10^{0}$ up to $10^{8}$ cells, is linear, i.e. even a low dose has the capability to kill all the cells that may be present in some patients, whereas a higher dose has the capability to eradicate all subclinical cancer deposits in a higher proportion of the patients $[13,14]$. A dose of about 50 Gy over 5 weeks (or a comparable dose using other fractionation schedules [15]) has the capability to prevent a recurrence within the irradiated volume in about $85-90 \%$ of patients. This knowledge is mainly based upon studies in breast and head and neck cancer. It is, however, likely that subclinical disease of most solid tumours respond to about the same extent [14]. The experience in rectal cancer shows that it responds similarly $[16,17]$. Thus, even if no direct knowledge is available for gastric and pancreatic cancer, it is not likely that these tumours will respond fundamentally differently. Consequently, even if, for example, pancreatic cancers as a group frequently contain genetic changes that may be associated with poor radiation sensitivity [18-20], there is reason to believe that the results seen in other gastrointestinal cancers potentially can also be seen in pancreatic cancer.

Much evidence indicates that preoperative radiotherapy is more dose-effective than postoperative radiotherapy, i.e. a certain dose has a higher probability of eradicating all subclinical cells in a surgically non-disturbed tissue than after the surgery $[13,17]$. Repopulation of cells in the postoperative phase and a greater probability of hypoxia in the surgical bed are the two most likely reasons for the lower efficacy of postoperative radiotherapy. It is possible that a dose of about $60 \mathrm{~Gy}$ is required postoperatively in order to reach the same reduction as can be achieved using 50 Gy preoperatively. 


\section{Surgery, Chemotherapy, Radiotherapy or All Three?}

Surgery will remain the most important method to remove the many tumour cells that are present in a visible tumour like a primary abdominal adenocarcinoma within the foreseeable future. The disadvantage with surgery is the morbidity that is seen once it aims at removing microscopic deposits from large tissue volumes. Radiotherapy has the advantage of covering a larger tissue volume with less morbidity than surgery, and eradicating all the tumour cells provided they are microscopic in size. The disadvantage with radiotherapy is that large volumes of the abdominal cavity cannot be irradiated to sufficiently high doses. The relations between tolerable radiation doses and volumes within different parts of the cavity are complex and only partly known. The entire cavity would hardly tolerate doses higher than 15-18 Gy, whereas limited volumes (a few decilitres) could tolerate 60 Gy or more. The tissue volumes at risk of containing tumour deposits in connection with a primary abdominal cancer can amount to several litres. Such volumes can hardly tolerate doses higher than 40-50 Gy. Larger volumes can generally be irradiated in the pelvis than in the abdomen.

With these figures in mind, and with the knowledge that the dose-response relationship of subclinical disease to radiotherapy is linear [14], radiotherapy has a reasonable chance of reducing local failure rates. Preoperative radiotherapy has an even higher probability than postoperative radiotherapy.

Cytostatic drugs or, in the future, more sophisticated drugs have the definite advantage of no geographical restriction. The efficacy, however, is still limited. It can be estimated that the cell-killing effect of 6 months of adjuvant chemotherapy for breast and colon cancer, for example, corresponds to a (whole-body) dose of about $15 \mathrm{~Gy}$ (prevents every fourth to third recurrence).

Radiotherapy and chemotherapy may co-operate spatially but may also, provided the cell-killing effects are independent of each other, be additive. Synergy is theoretically possible and has been much aimed at, but has not yet been seen clinically [21-24]. Yet, clinical gains have been seen in various tumour types, predominantly squamous cell carcinomas in the head and neck, oesophagus, lung, cervix and anus, but also in abdominal adenocarcinoma, using concomitant radiochemotherapy [25-28]. Radiochemotherapy has also gained much popularity, and whenever radiotherapy is used for a gastrointestinal malignancy, it is preferentially given with concomitant chemotherapy [29]. The scientific support for this use in abdominal malignancies is not, however, particularly strong, as will be discussed below. Since spatial co-operation is highly relevant, and additivity may be seen against loco-regional disease, it appears as if the best radiochemotherapy combination is when both modalities can safely be given together at the same doses as when used alone, i.e. the toxicity is non-overlapping. Thus, if only a fraction of the chemotherapy dose, for example, can be given with radiotherapy because of acute toxicity, this would, according to the opinion of this reviewer, disqualify the combination from further testing. Rather, the opposite has happened. The finding that only low doses of gemcitabine could be given with radiotherapy (or only low doses of radiotherapy with normal doses of gemcitabine) has, on the contrary, been taken as an indication of a promising combination to explore further $[23,30]$. The spatial cooperation will be absent and although selective synergy for tumour cells is still possible, this is not a likely event.

\section{Clinical Effects in Abdominal Malignancies}

Adjuvant chemoradiotherapy to decrease the risk of recurrence, and thus improve survival, has mainly been tried in rectal cancer, but also in pancreatic and gastric cancer. The use in other abdominal cancers is limited [31, 32] and will not be further reviewed here.

\section{Rectal Cancer}

In patients with a technically resectable cancer, generally constituting $85-90 \%$ of patients with a newly diagnosed rectal cancer, radio(chemo)therapy has been extensively used to lower unacceptably high local failure rates seen after surgery alone [33, 34]. The radiotherapy has been given either before or after the surgery, or occasionally both before and after. Large randomised trials have shown that preoperative radiotherapy can substantially decrease local failure rates and, unless counterbalanced by increased postoperative mortality, as seen in some trials [35], slightly improve overall survival [36, 37]. In this situation, radiotherapy has seldom been combined with chemotherapy, although this is being tested in an ongoing trial by the European Organization for Research and Treatment of Cancer (EORTC; protocol 22921).

Randomised trials have also shown that postoperative radiotherapy may decrease local failure rates, although to a lower extent than reached by preoperative radiotherapy [17], but without any influence on overall survival. Postoperatively, radiochemotherapy, rather than radiotherapy alone, has been used in several of the trials and has 
Table 1. Postoperative radiotherapy, chemotherapy or radiochemotherapy: results of randomised trials in rectal cancer stages II + III (trials only comparing two radiochemotherapy regimens are not included in the table)

\begin{tabular}{|c|c|c|c|c|}
\hline Trial, year & Study arms & Patient population & Results & Comments \\
\hline $\begin{array}{l}\text { GITSG } 7175 \\
1985,1986 \\
{[38,39]}\end{array}$ & $\begin{array}{l}\text { A: surgery alone } \\
\text { B: surgery + RT } 40-48 \text { Gy } \\
\text { C: surgery + CHT (MF) } \\
\text { D: surgery + RT + 5-FU + CHT } \\
\text { (MF) }\end{array}$ & $\begin{array}{l}\text { 1975-1980 } \\
202 / 227 \text { eligible } \\
\text { A: } 58 \text { pts } \\
\text { B: } 50 \text { pts } \\
\text { C: } 48 \text { pts } \\
\text { D: } 46 \text { pts }\end{array}$ & $\begin{array}{l}\text { 5-year local failure rate } \\
\text { A: } 24 \%, \text { B: } 20 \%, \text { C: } 27 \%, \text { D: } 11 \%(\mathrm{NS}) \\
\text { 6-year overall survival } \\
\text { A: } 28 \%, \text { B: } 43 \%, \text { C: } 43 \% \text {, D: } 57 \% \\
(p=0.05)\end{array}$ & $\begin{array}{l}\text { small trial, prematurely interrupted, } \\
\text { supports the benefit of postop RTCHT; } \\
\text { increased acute toxicity was seen }\end{array}$ \\
\hline $\begin{array}{l}\text { NCCTG } 794751 \\
1991 \\
{[40,74]}\end{array}$ & $\begin{array}{l}\text { A: RT } 45 \mathrm{~Gy} \pm \text { boost } 5.4 \mathrm{~Gy} \\
\text { B: same RT + 5-FU + CHT } \\
\text { (MF) }\end{array}$ & $\begin{array}{l}\text { 1980-1986 } \\
204 / 209 \text { eligible } \\
\text { A: } 100 \text { pts } \\
\text { B: } 104 \text { pts }\end{array}$ & $\begin{array}{l}\text { 5-year local failure rate } \\
\text { A: } 25 \%, B: 14 \%(p=0.04) \\
5 \text {-year overall survival } \\
\text { A: } 47 \%, B: 58 \%(p=0.04)\end{array}$ & $\begin{array}{l}\text { supports the benefit of combined RTCHT } \\
\text { over RT alone; increased acute toxicity, } \\
\text { particularly diarrhoea (grade } 3-422 \text { vs. } 4 \% \text {, } \\
\text { p = 0.001) }\end{array}$ \\
\hline $\begin{array}{l}\text { NSABP-R01 } \\
1988 \\
{[41]}\end{array}$ & $\begin{array}{l}\text { A: surgery alone } \\
\text { B: surgery + RT } 46.5 \mathrm{~Gy} \\
\text { C: surgery + CHT (MOF) }\end{array}$ & $\begin{array}{l}\text { 1977-1986 } \\
555 / 574 \text { eligible } \\
\text { A: } 185 \text { pts } \\
\text { B: } 184 \text { pts } \\
\text { C: } 187 \text { pts }\end{array}$ & $\begin{array}{l}\text { 5-year local failure rate } \\
\text { A: } 25 \%, \text { B: } 16 \%, \text { C: } 21 \%(\mathrm{NS}) \\
\text { 5-year overall survival } \\
\text { A: } 43 \%, \text { B: } 41 \%, \text { C: } 53 \%(p=0.05)\end{array}$ & $\begin{array}{l}\text { no benefit was seen with postoperative RT; } \\
\text { a survival benefit was seen with CHT alone, } \\
\text { challenging the results of the GITSG } 7175 \\
\text { trial - the benefit was restricted to males }\end{array}$ \\
\hline $\begin{array}{l}\text { ECOG-EST } \\
1991 \\
{[46]}\end{array}$ & $\begin{array}{l}\text { A: RT } \\
\text { B: CHT (MF) } \\
\text { C: RT + CHT }\end{array}$ & $\begin{array}{l}1986-? \\
248 \text { eligible } \\
237 \text { evaluable }\end{array}$ & $\begin{array}{l}\text { overall survival } \\
\text { A: } 46 \%, \text { B: } 47 \%, \text { C: } 50 \%(\mathrm{NS})\end{array}$ & $\begin{array}{l}\text { only reported as an abstract; no concomitant } \\
\text { CHT was given; gives no evidence of any } \\
\text { survival benefit }\end{array}$ \\
\hline $\begin{array}{l}\text { Tveit et al. } \\
1997 \\
{[42]}\end{array}$ & $\begin{array}{l}\text { A: surgery alone } \\
\text { B: surgery }+\mathrm{RT}+5-\mathrm{FU}\end{array}$ & $\begin{array}{l}1987-1991 \\
\text { A: } 72 \mathrm{pts} \\
\text { B: } 72 \mathrm{pts}\end{array}$ & $\begin{array}{l}\text { local failure rate } \\
\text { A: } 32 \%, B: 11 \%(p=0.01) \\
\text { overall survival } \\
\text { A: } 49 \%, B: 63 \%(p=0.05)\end{array}$ & $\begin{array}{l}\text { small trial, but supports the benefit of con- } \\
\text { comitant RTCHT without prolonged CHT }\end{array}$ \\
\hline $\begin{array}{l}\text { Cafiero et al. } \\
2000 \\
{[75]}\end{array}$ & $\begin{array}{l}\text { A: RT } 50 \text { Gy } \\
\text { B: CHT } \times 1+\text { RT }+ \text { CHT } \times 5 \\
(5-\mathrm{FU}+\text { levamisole })\end{array}$ & $\begin{array}{l}1992-1998 \\
\text { A: } 108 \mathrm{pts} \\
\text { B: } 110 \mathrm{pts}\end{array}$ & $\begin{array}{l}\text { local failure rate } \\
\text { A: } 15 \%, \text { B: } 21 \%(\mathrm{NS}) \\
\text { projected 5-year survival } \\
\text { A: } 56 \%, \mathrm{~B}: 39 \%(\mathrm{NS})\end{array}$ & $\begin{array}{l}\text { no benefit was seen with CHT in addition to } \\
\text { postoperative } \mathrm{RT} \text {; increased acute toxicity, } \\
\text { with significantly more severe enteritis } \\
(\mathrm{p}=0.03)\end{array}$ \\
\hline $\begin{array}{l}\text { NSABP-R02 } \\
2000 \\
{[44]}\end{array}$ & $\begin{array}{l}\text { A: CHT (MOF or FLv) } \\
\text { B: CHT + RT } 45 \text { Gy + boost } \\
5.4 \text { Gy + 5-FU + CHT }\end{array}$ & $\begin{array}{l}\text { 1987-1992 } \\
694 / 742 \text { eligible } \\
\text { A: } 348 \text { pts } \\
\text { B: } 346 \text { pts }\end{array}$ & $\begin{array}{l}\text { 8-year initial local failure rate } \\
\text { A: } 14 \%, B: 8 \%(\mathrm{p}=0.02) \\
\text { 8-year overall survival } \\
\text { A = B: } 58 \%(\mathrm{p}=0.9)\end{array}$ & $\begin{array}{l}\text { RT with CHT decreased local failure rates } \\
\text { but did not improve survival }\end{array}$ \\
\hline
\end{tabular}

$\mathrm{CHT}=$ Chemotherapy $; \mathrm{FLv}=5-\mathrm{FU}+$ leucovorin $; \mathrm{MF}=$ methyl-CCNU + 5-FU; $\mathrm{MOF}=$ methyl-CCNU + vincristine + 5-FU; pts = patient(s);

$\mathrm{RT}=$ radiotherapy RTCHT $=$ radiochemotherapy NCCTG = North Central Cancer Treatment Group; ECOG = Eastern Co-operative Oncology Group; NS = not significant.

tended to decrease local failure rates and significantly improve survival compared with surgery alone or surgery and postoperative radiotherapy (table 1) [38-42]. A survival benefit was, however, seen with postoperative chemotherapy alone without any radiotherapy in the trial (Protocol R-01) conducted by the National Surgical Adjuvant Breast and Bowel Project (NSABP) [41].

In 1990, a US NIH Consensus Conference recommended postoperative chemoradiotherapy as standard treatment for rectal cancer in stages II and III [43]. The consensus statement was based upon the results of three of the randomised trials mentioned above [38-41]. The results of the studies can, however, be interpreted differently; it is actually possible that the survival benefit may be ascribed to the systemic effects of the chemotherapy component and not to improved local control offered by, for example, radiosensitization. The Gastrointestinal Tumor Study Group (GITSG) trial was severely underpowered to reveal any benefit from either radiotherapy or chemotherapy alone [38, 39]. This conclusion is further supported by a follow-up trial by the NSABP (Protocol R-02). In that trial, postoperative chemotherapy was given to all patients, whereas postoperative radiotherapy was randomly assigned to half of the 694 eligible patients. The radiotherapy had no beneficial effect on disease-free or overall survival, although it slightly reduced the cumulative incidence of locoregional relapse from 13 to $8 \%$ at 5 -year follow-up $(p=0.02)$ [44]. The role of the radiotherapy component in the postoperative radiochemotherapy with respect to the survival gain can thus be questioned. If 
Table 2. Postoperative chemotherapy or radiochemotherapy: randomised trials in pancreatic cancer (trials only comparing two active treatments are not included)

\begin{tabular}{|c|c|c|c|c|}
\hline Trial, year & Study arms & Patient population & Results & Comments \\
\hline $\begin{array}{l}\text { Bakkevold } \\
\text { et al. } 1993 \\
{[49]}\end{array}$ & $\begin{array}{l}\text { A: surgery alone } \\
\text { B: surgery + CHT (FAM) }\end{array}$ & $\begin{array}{l}1984-1987 \\
61 / 110 \text { randomised } \\
\text { A: } 31 \text { pts } \\
\text { B: } 30 \text { pts }\end{array}$ & $\begin{array}{l}\text { median survival } \\
\text { A: } 11 \mathrm{mts}, \mathrm{B}: 23 \mathrm{mts}(\mathrm{p}=0.02) \\
\text { 2-year overall survival } \\
\text { no difference }\end{array}$ & $\begin{array}{l}\text { small trial; a short-term benefit was seen; } \\
\text { toxicity was significant, which could diminish } \\
\text { the effect since only } 13 \text { patients }(43 \%) \\
\text { completed } 6 \text { cycles }\end{array}$ \\
\hline $\begin{array}{l}\text { Amano } \\
\text { et al. } 1999 \\
{[50]}\end{array}$ & $\begin{array}{l}\text { A: surgery alone } \\
\text { B: surgery + CHT (MF) }\end{array}$ & $\begin{array}{l}1988-1992 \\
158 \text { pts }\end{array}$ & $\begin{array}{l}\text { 5-year survival } \\
\text { A: } 18 \%, \mathrm{~B}: 12 \%(\mathrm{NS})\end{array}$ & $\begin{array}{l}\text { only reported as an abstract; no benefit was } \\
\text { seen; also included patients with periampullary } \\
\text { and biliary cancer }\end{array}$ \\
\hline $\begin{array}{l}\text { GITSG } \\
1985 \\
{[51]}\end{array}$ & $\begin{array}{l}\text { A: surgery alone } \\
\text { B: surgery }+ \text { RTCHT } \\
(40 \text { Gy }+5-F U)\end{array}$ & $\begin{array}{l}\text { 1974-1982 } \\
43 / 49 \text { eligible } \\
\text { A: } 21 \text { pts } \\
\text { B: } 22 \text { pts }\end{array}$ & $\begin{array}{l}\text { 2-year survival } \\
\text { A: } 18 \%, \text { B: } 43 \% \\
\text { 5-year survival } \\
\text { A: } 8 \%, \text { B: } 18 \%(p=0.04)\end{array}$ & $\begin{array}{l}\text { very small trial that took many years for several } \\
\text { hospitals to complete; shows a survival benefit } \\
\text { with RTCHT; discussed extensively, but } \\
\text { considered by some sufficient evidence for } \\
\text { postoperative RTCHT }\end{array}$ \\
\hline $\begin{array}{l}\text { EORTC } \\
1999 \\
{[52]}\end{array}$ & $\begin{array}{l}\text { A: surgery alone } \\
\text { B: surgery + RTCHT } \\
\text { (40 Gy with 5-FU) }\end{array}$ & $\begin{array}{l}\text { 1987-1995 } \\
208 / 218 \text { eligible } \\
\text { A: } 108 \text { pts } \\
\text { B: } 110 \text { pts }\end{array}$ & $\begin{array}{l}\text { median survival } \\
\text { A: } 19 \mathrm{mts}, \mathrm{B}: 25 \mathrm{mts}(\mathrm{p}=0.2) \\
\text { 2-year survival } \\
\text { A: } 41 \%, \mathrm{~B}: 51 \%(\mathrm{p}=0.1)\end{array}$ & $\begin{array}{l}\text { trend towards improved survival with RTCHT } \\
\text { was seen, but underpowered; } 21 \% \text { of the } \\
\text { patients did not receive any therapy; } \\
\text { included also periampullary cancers }\end{array}$ \\
\hline $\begin{array}{l}\text { ESPAC-1 } \\
2001 \\
{[53]}\end{array}$ & $\begin{array}{l}\text { A: surgery alone } \\
\text { B: surgery + CHT (FLv) } \\
\text { C: surgery + RTCHT } \\
\text { (40 Gy with 5-FU) } \\
\text { D: surgery + RTCHT + CHT }\end{array}$ & $\begin{array}{l}\text { 1994-2000 } \\
\text { no RTCHT: } 178 \text { pts } \\
\text { RTCHT: } 175 \text { pts } \\
\text { no CHT: } 235 \text { pts } \\
\text { CHT: } 238 \text { pts }\end{array}$ & $\begin{array}{l}\text { median survival } \\
\text { no RTCHT + RTCHT: } 16 \mathrm{mts}(\mathrm{NS}) \\
\text { no CHT: } 14 \mathrm{mts} \\
\text { CHT: } 20 \mathrm{mts}(\mathrm{p}=0.005)\end{array}$ & $\begin{array}{l}\text { pts could be randomised to } 2 \text { arms or } 4 \text { arms in } \\
\text { a } 2 \times 2 \text { factorial design; no benefit of RTCHT } \\
\text { was seen, whereas it was with CHT; } \\
\text { the benefit was seen in all strata }\end{array}$ \\
\hline
\end{tabular}

$\mathrm{CHT}=$ Chemotherapy; FAM = 5-FU + doxorubicin + mitomycin-C; MF = methyl-CCNU + 5-FU; RTCHT = radiochemotherapy;

$\mathrm{FLv}=5-\mathrm{FU}+$ leucovorin; $\mathrm{pts}=$ patients; $\mathrm{mts}=$ months; NS = not significant.

radiochemotherapy is used postoperatively, protracted infusion of 5-fluorouracil (5-FU) is superior to bolus 5-FU during the radiotherapy [45]. This treatment may thus be considered as a reference regimen if a combined approach is used postoperatively, since superiority has been shown in one large randomised trial.

Several other randomised trials add information on the relevance of postoperative radio(chemo)therapy. In a Norwegian trial, 144 patients were randomised to surgery alone, and postoperative radiotherapy with bolus 5-FU was given only during the radiotherapy [42]. A clear benefit with respect to both local control rate and survival was seen, indirectly supporting the efficacy of concomitant administration. In another US trial (Eastern Co-operative Oncology Group, study EST 4276), only reported as an abstract in 1991 [46], no influence on either local control rate or survival was seen from sequential postoperative radiotherapy and chemotherapy compared with surgery alone. This apparently negative trial, never published in full, was not considered in the NIH document. Since concomitant chemoradiotherapy was not used, the trial data also indirectly support the relevance of concomitant administration. An Hellenic group studied the value of add- ing three cycles of bolus 5-FU and leucovorin after one cycle of the same regimen and radiotherapy with bolus 5-FU [47]. No difference could be seen in the trial involving 220 patients, excluding a major influence on survival of the postoperative chemotherapy component. Neither addition of leucovorin nor levamisole to 5-FU and radiotherapy showed an influence on control rates or survival in a large randomised trial including 1,696 patients [48]. Thus, there is no evidence that modulated 5-FU is superior to 5-FU alone when combined with radiotherapy, as is the case when chemotherapy is used alone for metastatic disease [10].

Taking these results together, it is not possible to define an optimal combination of chemotherapy and radiation postoperatively in rectal cancer patients in stages II and III. It is actually not even possible to state that a combination is superior to either modality alone, although this is likely the case.

\section{Pancreatic Cancer}

Five randomised studies of adjuvant (radio)chemotherapy following pancreatic resection for cancer are available (table 2). A modified regimen of 5-FU, doxoru- 
bicin and mitomycin-C was given every 3 weeks for six cycles after resection in one trial [49]. Of 110 patients with radical pancreatic resection, 61 were eligible for randomisation. The median survival was significantly longer in the treatment group than in the control group $(\mathrm{p}=$ 0.02). The difference was attributed to a survival benefit in the treatment group during the first 2 years.

A large Japanese randomised study of 158 patients with pancreatic cancer could not detect any benefit of postoperative chemotherapy using 5-FU and mitomycin $\mathrm{C}$ [50]. The study showed, however, a significant survival benefit for gallbladder cancer $(\mathrm{n}=112)$, but no such benefit was observed for bile duct $(\mathrm{n}=118)$ and periampullary cancer $(n=48)$.

5-FU has been used together with external radiotherapy in three randomised trials with a surgery-alone group [51-53]. In the first trial, performed by the GITSG, 5-FU was administered together with 40 Gy of external radiotherapy to 22 patients after radical pancreatectomy [51]. A statistically significant difference in survival was found between the treated patients and the non-treated controls (table 2). Similar results were reported from a phase II study using the same regimen of postoperative radiation and 5-FU treatment [54]. In these studies, good tolerance to the treatment regimen was noted.

In the second trial, performed by the EORTC [52], split-course chemoradiation as used in the GITSG trial was administered without maintenance chemotherapy. A total of 218 patients were randomised, 119 with pancreatic head cancers and 109 with periampullary cancers. In patients with pancreatic cancer, median and 2-year survival rates tended to be better for patients randomised to chemoradiotherapy than for patients randomised to the control condition. There were no significant differences among patients with periampullary cancers. Overall, therapy was well tolerated, but $22 \%$ of the patients in the treatment group did not receive any treatment because of postoperative morbidity or patient refusal after randomisation.

The European Study Group for Pancreatic Cancer (ESPAC-1) assessed the role of postoperative chemoradiotherapy or chemotherapy in a randomised trial of 541 patients with ductal pancreatic adenocarcinoma [53]. A two-by-two factorial design was used. After resection, patients were randomly assigned to adjuvant chemoradiotherapy using a split course with $40 \mathrm{~Gy}$ and 5-FU or chemotherapy with 5-FU-leucovorin according to the Mayo schedule for 6 months. Patients could be randomised to observation, chemoradiotherapy alone, chemotherapy alone or both. After a median follow-up of 10 months for patients still alive, the results showed no benefit of adjuvant chemoradiotherapy, whereas there was evidence of a survival benefit with adjuvant chemotherapy (table 2). Toxicity data were available only in a subset of patients, and $27 \%$ reported serious toxic effects, predominantly when chemotherapy was used alone. The follow-up is not long enough to assess whether the proportions of patients alive after 3 or 5 years will differ.

Evidence that adjuvant treatment should routinely be used in pancreatic cancer is presently not available. The small US GITSG study [51] has been discussed extensively during the past 15 years and the interpretation of the apparently positive trial data has varied considerably. The methodological weaknesses of the trial are so pronounced that it cannot form the basis for a recommendation of general treatment outside clinical trials. This is further supported by the EORTC trial [52]. The trial was negative $(p=0.1)$ but underpowered $(n=119)$. A joint committee of US co-operative groups recently reached a conclusion to the contrary [30]. Even if the committee recognized that 'purists will demand to know where the notreatment arm is to be found', it suggested a study (RTOG 9704) that has two active post-surgical chemoradiation arms [30]. The trial data, together with the positive results of the Norwegian trial [49] and ESPAC-1 [53], indicate, however, that further trials, properly controlled, are important. The ESPAC-1 has rolled into ESPAC-3, randomising between surgery alone, 5-FU with leucovorin and gemcitabine. The future of adjuvant treatment of pancreatic and periampullary cancers is dependent on the results of this and comparable trials.

Two randomised trials have provided some evidence that chemoradiation is slightly superior to either modality alone in patients with inoperable pancreatic cancer. In a trial by the GITSG that included 194 patients, a slight gain in survival was seen when 5-FU was added to postoperative radiotherapy (40 or $60 \mathrm{~Gy}$ ) compared with radiotherapy alone $(60 \mathrm{~Gy}$; median survival 8 vs. 5 months, $\mathrm{p}<0.01$ ) [55]. Chemotherapy alone (the SMF regimen, streptozotocin, mitomycin-C, 5-FU) was inferior to the combination of 5-FU and radiation ( $54 \mathrm{~Gy}$; median survival 8 vs. 10.5 months, $\mathrm{p}<0.02$ ) in a trial involving 43 patients [56]. In yet another randomised trial by the GITSG, doxorubicin and radiation were compared with 5-FU and radiation in 157 patients. In this study, however, there was no evidence of superiority of either schedule [57]. 
Table 3. Postoperative radio(chemo)therapy: results of randomised trials in gastric cancer

\begin{tabular}{|c|c|c|c|c|}
\hline Trial, year & Study arms & Patient population & Results & Comments \\
\hline $\begin{array}{l}\text { Mayo } \\
1974 \\
{[59]}\end{array}$ & $\begin{array}{l}\text { A: surgery + RT } \\
\text { B: surgery + RT with 5-FU }\end{array}$ & $\begin{array}{l}\text { study period unknown } \\
\text { A: } 23 \text { pts } \\
\text { B: } 25 \text { pts }\end{array}$ & $\begin{array}{l}\text { mean survival } \\
\text { A: } 6 \text { mts, B: } 13 \mathrm{mts}(\mathrm{p}<0.05) \\
5 \text {-year survival } \\
\text { A: } 0 \%, \text { B: } 12 \%\end{array}$ & $\begin{array}{l}\text { included unresected or residual cancers; } \\
\text { small trial that showed benefit for RTCHT } \\
\text { versus RT alone }\end{array}$ \\
\hline $\begin{array}{l}\text { GITSG } \\
1982 \\
{[60,61]}\end{array}$ & $\begin{array}{l}\text { A: surgery + CHT (MF) } \\
\text { B: surgery + RT ( } 50 \text { Gy) with } \\
\text { 5-FU + CHT }\end{array}$ & $\begin{array}{l}\text { 1975-1977 } \\
\text { 90/96 eligible } \\
\text { A: } 45 \text { pts } \\
\text { B: } 45 \text { pts }\end{array}$ & $\begin{array}{l}\text { 5-year survival } \\
\text { A: } 7 \%, B: 16 \%(p<0.05)\end{array}$ & $\begin{array}{l}\text { included pts with residual tumour; RTCHT } \\
\text { appeared more effective than CHT alone } \\
\text { after long follow-up, but showed substantial } \\
\text { toxicity with initially inferior survival }\end{array}$ \\
\hline $\begin{array}{l}\text { EORTC } \\
1989 \\
{[62]}\end{array}$ & $\begin{array}{l}\text { A: surgery + RT ( } 55 \text { Gy) } \\
\text { B: surgery + RT with short 5-FU } \\
\text { C: surgery + RT with long 5-FU } \\
\text { D: surgery + RT with short + } \\
\text { long 5-FU }\end{array}$ & $\begin{array}{l}\text { 1972-1978 } \\
\text { A: } 30 \text { pts } \\
\text { B: } 30 \text { pts } \\
\text { C: } 26 \text { pts } \\
\text { D: } 29 \text { pts }\end{array}$ & $\begin{array}{l}\text { median survival } \\
\text { A: } 12 \mathrm{mts}, \mathrm{B}: 19 \mathrm{mts}, \mathrm{C}: 15 \mathrm{mts} \text {; } \\
\text { D: } 18 \mathrm{mts}(\mathrm{p}=0.04)\end{array}$ & $\begin{array}{l}\text { both curatively and palliatively resected pts } \\
\text { included; subgroup analyses show that pro- } \\
\text { longed RTCHT may indicate increased chance } \\
\text { of long-term survival }\end{array}$ \\
\hline $\begin{array}{l}\text { US Intergroup } \\
2001 \\
{[63]}\end{array}$ & $\begin{array}{l}\text { A: surgery alone } \\
\text { B: surgery + RT ( } 45 \text { Gy) with } \\
\text { 5-FU + CHT (FLv) }\end{array}$ & $\begin{array}{l}\text { 1991-1998 } \\
556 / 603 \text { eligible } \\
\text { A: } 275 \text { pts } \\
\text { B: } 281 \text { pts }\end{array}$ & $\begin{array}{l}\text { median survival } \\
\text { A: } 27 \mathrm{mts}, \mathrm{B}: 36 \mathrm{mts}(\mathrm{p}=0.005) \\
\text { 3-year survival } \\
\text { A: } 41 \%, \mathrm{~B}: 50 \%\end{array}$ & $\begin{array}{l}\text { large trial which included only radically resected } \\
\text { cancers; showed a survival benefit for } \\
\text { postoperative RTCHT, seen irrespective of the } \\
\text { extent of surgery (D0-2); toxic, but manageable }\end{array}$ \\
\hline
\end{tabular}

\section{Gastric Cancer}

A great number of randomised trials have explored the value of adjuvant chemotherapy after gastric cancer surgery. Collectively, they do not indicate any relevant survival gain [58]

Four trials, three early and small, and one recent and large, have explored the value of radiochemotherapy in gastric cancer in a controlled way (table 3 ). In an early randomised trial from the Mayo Clinic, patients with unresected or residual gastric cancers were treated with radiotherapy alone or radiation plus concomitant bolus 5-FU. Mean and 5-year survival were more favourable with combined therapy [59]. The GITSG [60] randomised 90 eligible patients to receive either combination chemotherapy alone (5-FU and methyl-CCNU) or a split course of 50 Gy with bolus 5-FU on days 1-3 of each 25Gy course of radiotherapy to the regional residual disease, followed by 5 -FU plus methyl-CCNU. All patients had histologically proven adenocarcinoma, gross or microscopic local residual tumour and no metastatic disease. Survival was initially inferior for the radiochemotherapy arm because of myelosuppression and nutritional complications. However, with a minimum of 5 years of followup, survival was statistically improved $(\mathrm{p}<0.05)$ in the combined radiochemotherapy arm [61]. Bleiberg et al. [62] tested the value of various sequences of 5-FU with radiation $(55.5 \mathrm{~Gy})$ versus radiation alone after curative or palliative gastric resection. All long-term survivors with postoperative residual disease received concomitant radiochemotherapy, and 5-FU-based chemotherapy was also associated with improved overall survival $(p=0.04)$. However, when the comparisons were adjusted for the most significant prognostic factors, the difference in survival disappeared. Moreover, no difference was found between treatments in terms of time to progression. The three trials give some support to the superiority of radiochemotherapy compared with radiotherapy, but since they exclusively or predominantly included non-resected or palliatively resected cases, they do not give any information about the role of adjuvant radiochemotherapy.

In the fourth and by far the largest trial, a US Intergroup Study recently reported improved survival after postoperative radiochemotherapy [63]. Altogether, 556 patients with resected gastric cancer were randomly assigned to surgery alone or surgery plus postoperative radiochemotherapy. The adjuvant treatment consisted of one course of 5-FU plus leucovorin over 5 days (Mayo Clinic schedule), followed by $45 \mathrm{~Gy}$ of radiation for 5 weeks with 5-FU and leucovorin, followed by two more cycles of 5-FU-leucovorin. An extensive quality assurance (QA) and quality control assessment of the radiotherapy was included in the trial. This procedure revealed inappropriate radiotherapy planning in a large proportion of patients. Forty-four percent of the patients had a D0 
lymphadenectomy, i.e. a resection in which not all of the N1 nodes were removed, $36 \%$ had a D1 dissection and only $10 \%$ a D2 dissection. The median overall survival was longer in the chemoradiotherapy group (table 3 ). The survival curves indicate that the benefit was maintained beyond 5 years. Toxicity to treatment was predominantly haematologic and gastrointestinal, and grade III or greater toxicity was seen in $41 \%$ of the patients.

\section{Why Is Postoperative Radiochemotherapy Effective in Rectal and Gastric Cancer but Not in Pancreatic Cancer?}

The randomised trials described above had opposite results concerning the influence of postoperative radiochemotherapy on survival for the three major abdominal cancers. Most oncologists would immediately agree that these results could be anticipated in advance. Firstly, gastric and colorectal cancer show higher sensitivity, at least in the short-term, to both radiotherapy and chemotherapy than pancreatic cancer $[10,58,64]$. Pancreatic cancer contains a number of molecular changes, all suspected to confer chemoradioresistance in other tumours [18, 19, 65], and more frequently has distant metastases than both rectal and gastric cancer. Secondly, the radiotherapy dose used in the pancreatic trial (40-Gy split dose) was lower than the dose in the gastric cancer trial (45 Gy) and in the rectal cancer trials (46-50 Gy). It is difficult to argue against these explanations of the contrasting results between tumour sites.

There is, however, an additional explanation. In the gastric cancer trial, the clinical target volume was clearly defined and included the tumour bed, the regional lymph nodes and a margin beyond the resection margins. Extensive QA and quality control assessments of the radiotherapy plans were made both prior to the treatment and afterwards. Much emphasis has been placed on the radiation techniques in rectal cancer trials [66]. In the pragmatic pancreatic cancer trial, details of the radiotherapy were not given in the publication and only local QA procedures were available. Although not known, it is possible that many patients only had radiotherapy of the tumour bed with margins. Admittedly, it is easy to blame failures on improper 'whatever you can think of', and radiation oncologists may in this respect be no exception (some would actually argue that we are among the worst). I would argue that adequate coverage of not only the resection bed but of all regional lymph nodes is essential for effective radiotherapy, whether given pre- or postoperatively, and that this is more important than the radiotherapy dose. It is known, as discussed above, that the dose-response relationship to radiotherapy for subclinical disease is linear and, therefore, some effects could be seen also using rather low doses [14, 16]. Regional node involvement is extremely common in pancreatic cancer. Using sensitive markers (immunohistochemistry, PCR-based techniques), tumor cells can be found in $100 \%$ of cases, even in nodes only removed during an extended lymph node dissection [67]. If lymph node metastases are seen, distant metastases are extremely common, albeit not present in $100 \%$ of cases. Thus, there may be an opportunity for an effect of regional therapy such as radiotherapy. The regional therapy, whether extended surgery or radiotherapy, must then cover all regional nodes at risk of containing tumour cells and not just those easily removed/irradiated.

\section{Compensation for Poor Surgery?}

Arguments have been submitted that the radiochemotherapy effect in gastric cancer is only a compensation for poor surgery. These arguments have repeatedly been raised also in rectal cancer radiotherapy. The recently reported total mesorectal excision trial, where surgery was at a higher quality level than was the case in all previous rectal cancer radiotherapy trials [37], clearly showed a benefit of radiotherapy in terms of fewer local recurrences also in combination with optimal surgery [68]. Actually, the relative efficacy of radiotherapy was higher with good surgery than with 'standard' surgery, as could be anticipated $[69,70]$. The hypothesis could then be raised that the positive radiochemotherapy effects seen in gastric cancer in the US trial [63] would be even larger if the patients had had adequate surgery (all at least a D1 resection). It is then possible that the radiotherapy coverage of the regional nodes must be more complete than is the case if surgery only removes that bulk of the tumour cells in order to lower the risk of failure. The success story in rectal cancer may be a result of rather large clinical target volumes, including not only the nodes close to the bowel but also all lateral nodes $[66,69]$. In some of the trials, however, unnecessarily large target volumes were selected, resulting in too much toxicity. Inappropriate techniques further increased radiation burden, and thus toxicity, in some trials $[69,70]$. 


\section{Need for Further Trials}

The extrapolations of trial data, including the comparisons made between different abdominal tumour sites described above, are all speculations. Speculations can never form the basis for treatment recommendations. Adjuvant therapy is thus not yet routine therapy in either gastric or pancreatic cancer. If based upon sound clinical and tumour biological knowledge, such speculations can, however, form the basis for hypotheses to be tested in proper trials. Thus, a European initiative for a large gastric cancer trial with good QA of all relevant aspects (staging, surgery, additional therapy and pathology) is urgently needed. In the US, a decision has already been made by some experts that postoperative radiochemotherapy is standard therapy [71]. In the report, detailed descriptions of the radiotherapy portals are given for various localisations of the primary tumour in the stomach.

In rectal cancer, major uncertainties regarding the best adjuvant therapy also remain. In Europe, preoperative radiotherapy is predominantly used, and the short Swedish schedule of $5 \times 5$ Gy has gained much popularity [70]. In the US, in contrast, postoperative radio(chemo)therapy is predominantly used [72]. When radiotherapy is given alone, all evidence points to the greater efficacy and tolerability of preoperative delivery $[17,37]$. The two most widely used approaches, i.e. preoperative $5 \times 5$ Gy over 1 week and postoperative radiochemotherapy over 6 months (radiotherapy over 5-6 weeks), have never been directly compared, although a Polish trial has completed patient recruitment [73]. The $5 \times 5$ Gy schedule has been tested against surgery alone in four large trials involving over 4,000 (4,061) patients, and was also found to be effective with total mesorectal excision, whereas the randomised evidence of a comparable efficacy of postoperative radiochemotherapy is limited to two trials involving a total of 346 patients.

\section{Conclusions}

The potentials, but also the limitations of various therapy modalities must be known and considered prior to designing combined therapy protocols. The differences in cell-killing/removal effects and the spatial differences between surgery, radiotherapy and chemotherapy illustrate that clinical gains can be achieved. Randomised trials have also shown that surgery followed by adjuvant radiochemotherapy has resulted in such gains in some abdominal malignancies. The gains have so far been limited, although clinically meaningful at least in rectal cancer. Since the gains are limited, better selection of the patients with the greatest need for additional therapy is required. It is also important in the future to be able to select those who will respond to the additional therapy.

When combining various therapies, timing is also relevant. It is likely that preoperative therapy may result in further gains, and this approach must be tested also at sites other than the rectum. The concomitant administration of radiotherapy and chemotherapy, although very popular and preferred by many, should also be the subject of trials to gain further knowledge about the balance between anti-tumour and normal tissue effects. Finally, more emphasis must be placed on the extent of both surgery and radiotherapy in order to remove as many tumour cells as possible with as little morbidity as possible.

\section{References}

1 Stenbeck M, Rosén M, Holm L-E: Cancer survival in Sweden during three decades, 19611991. Acta Oncol 1995;34:881-891.

2 Dickman PW: Hakulinen T, Luostarinen T, Pukkala E, Sankila R, Soderman B, Teppo L: Survival of cancer patients in Finland 19551994. Acta Oncol 1999;38(suppl 12):1-103.

3 Sant M, Capocaccia R, Coleman MP, Berrino F, Gatta G, Micheli A, Verdecchia A, Faivre J, Hakulinen T, Coebergh JW, Martinez-Garcia C, Forman D, Zappone A: Cancer survival increases in Europe, but international differences remain wide. Eur J Cancer 2001;37: 1659-1667.

4 Dahlberg M, Glimelius B, Påhlman L: Changing strategy for rectal cancer is associated with improved outcome. Br J Surg 1999;86:379_ 384.
5 Dahlberg M, Glimelius B, Påhlman L: Improved survival and reduction in local failure rates after preoperative radiotherapy: Evidence for the generalizability of the results of Swedish Rectal Cancer Trial. Ann Surg 1999;229:493497

6 Lehander Martling A, Holm T, Rutqvist L-E, Moran BJ, Heald RJ, Cedermark B: Effect of a surgical training programme on outcome of rectal cancer in the County of Stockholm. Lancet 2000;356:93-96.

7 Bonenkamp JJ, Hermans J, Sasako M, van de Velde CJ: Extended lymph-node dissection for gastric cancer. Dutch Gastric Cancer Group. N Engl J Med 1999;340:908-914.
8 Cuschieri A, Weeden S, Fielding J, Bancewicz J, Craven J, Joypaul V, Sydes M, Fayers P: Patient survival after $D_{1}$ and $D_{2}$ resections for gastric cancer: Long-term results of the MRC randomized surgical trial. Surgical Co-operative Group. Br J Cancer 1999;79:1522-1530.

9 Nygren P: What is cancer chemotherapy? Acta Oncol 2001;40:166-174.

10 Ragnhammar P, Hafström L, Nygren P, Glimelius B: A systematic overview of chemotherapy effects in colorectal cancer. Acta Oncol 2001;40:282-308.

11 Early Breast Cancer Treatment Collaborative Group. Polychemotherapy for early breast cancer: An overview of the randomised trials. Lancet 1998:352:930-942.

12 Bergh J, Jonsson PE, Glimelius B, Nygren P: A systematic overview of chemotherapy effects in breast cancer. Acta Oncol 2001;40:253-281. 
13 Fletcher GH: Subclinical disease. Cancer 1984; 53:1274-1284.

14 Withers HR, Peters LJ, Taylor JMG: Doseresponse relationship for radiation therapy of subclinical disease. Int $\mathrm{J}$ Radiat Oncol Biol Phys 1995;31:353-359.

15 Fowler JF: The linear-quadratic formula and progress in fractionated radiotherapy. Br J Radiol 1989;62:679-694.

16 Suwinski R, Taylor JMG, Withers HR: Rapid growth of microscopic rectal cancer as a determinant of response to preoperative radiation therapy. Int J Radiat Oncol Biol Phys 1998;42: 943-951.

17 Glimelius B, Isacsson U, Jung B, Påhlman L: Radiotherapy in addition to radical surgery in rectal cancer: Evidence for a dose-response effect favouring preoperative treatment. Int J Radiat Oncol Biol Phys 1997;37:281-287.

18 Blanck HM, Tolbert PE, Hoppin JA: Patterns of genetic alterations in pancreatic cancer: A pooled analysis. Environ Mol Mutagen 1999; 33:111-122.

19 Li D: Molecular epidemiology of pancreatic cancer. Cancer 2001;7:259-265.

20 Gatti RA: The inherited basis of human radiosensitivity. Acta Oncol 2001;40:702-711.

21 Byfield JE: 5-Fluorouracil radiation sensitization - a brief review. Invest New Drugs 1989;7: 111-116.

22 Steel GG: The search for therapeutic gain in the combination of radiotherapy and chemotherapy. Radiother Oncol 1988;11:31-53.

23 von der Maase $\mathrm{H}$ : Combined radiotherapy and chemotherapy; in Souhami RL, Tannock I, Hohenberger P, Horiot J-C (eds): Oxford Textbook of Oncology. Oxford, Oxford University Press, 2001, pp 489-509.

24 Schilsky RL: Biochemical pharmacology of chemotherapeutic drugs used as radiation enhancers. Semin Oncol 1992;19(suppl 11):2-7.

25 Pignon JP, Bourkis J, Domenge C, Designe L: Chemotherapy added to locoregional treatment of head and neck squamous carcinoma: Three meta-analyses of updated individual data. Lancet 2000;355:949-955.

26 Sternberg CN, Parmar MKB: Neoadjuvant chemotherapy is not (yet) standard treatment for muscle-invasive bladder cancer. J Clin Oncol 2001;19:21-26.

27 Albertsson M: Chemoradiotherapy of esophageal cancer. Acta Oncol 2002;41:118-123.

28 Rose PG, Bundy BN: Chemoradiation for locally advanced cervical cancer. Does it help? J Clin Oncol 2002;20:891-893.

29 Glimelius B: Chemoradiotherapy for recta cancer - is there an optimal combination? Ann Oncol 2001;12:1039-1045.

30 Regine WF, Abrams RA: Adjuvant therapy for pancreatic cancer: Back to the future. Int $\mathrm{J}$ Radiat Oncol Biol Phys 1998;42:59-63.

31 Kresl JJ, Schild SE, Henning GT, Gunderson LL, Donohue J, Pitot H, Haddock MG, Nagorney D: Adjuvant external beam radiation therapy with concurrent chemotherapy in the management of gallbladder carcinoma. Int J Radiat Oncol Biol Phys 2002;52:167-175.
32 Gunderson LL, Haddock MG, Burch P, Nagorney D, Foo ML, Todoroki T: Future role of radiotherapy as a component of treatment in biliopancreatic cancers. Ann Oncol 1999;10: 291-295.

33 Påhlman L, Glimelius B: Local recurrences after surgical treatment for rectal carcinoma. Acta Chir Scand 1984;150:331-335.

34 Kapiteijn E, Marijnen CA, Colenbrander AC, Klein Kranenbarg E, Steup WH, van Krieken $\mathrm{JH}$, van Houwelingen $\mathrm{JC}$, Leer JW, van de Velde CJ: Local recurrence in patients with rectal cancer diagnosed between 1988 and 1992: A population-based study in the west Netherlands. Eur J Surg Oncol 1998;24:528-535.

35 Holm T, Rutqvist LE, Johansson H, Cedermark B: Postoperative mortality in rectal cancer treated with or without preoperative radiotherapy: Causes and risk factors. Br J Surg 1996;83:964-968.

36 Swedish Rectal Cancer Trial: Improved survival with preoperative radiotherapy in resectable rectal cancer. N Engl J Med 1997;336:980987.

37 Colorectal Cancer Collaborative Group: Adjuvant therapy for rectal cancer: A systematic overview of 8,507 patients from 22 randomised trials. Lancet 2001;358:1291-1304.

38 Gastrointestinal Tumor Study Group: Prolongation of the disease-free interval in surgically treated rectal carcinoma. N Engl J Med 1985; 312:1465-1472.

39 Gastrointestinal Tumor Study Group: Survival after postoperative combination treatment of rectal cancer. N Engl J Med 1986;315:12941295.

40 Krook JE, Moertel CG, Gunderson LL, Wieand HS, Collins RT, Beart RW, Kubista TP, Poon MA, Meyers WG, Maillard JA, Twito DI, Morton RF, Veeder MH, Witzig TE, Cha S, Vidyarthi SC: Effective surgical adjuvant therapy for high-risk rectal cancer. N Engl J Med 1991;324:709-715.

41 Fisher B, Wolmark N, Rockette H, Redmond C, Deutsch M, Wickerman DL, Fisher ER, Caplan R, Jones J, Lerner H, Gordon P, Feldman M, Cruz A, Legault-Poisson S, Wewxler M, Laurence W, Robidoux A: Postoperative adjuvant chemotherapy or radiation therapy for rectal cancer: Results from NSABP Protocol R-01. J Natl Cancer Inst 1988;80:21-29.

42 Tveit KM, Guldvog I, Hagen S, Trondsen E, Harbitz T, Nygaard K, Nilsen JB, Wist E, Hannisdal E: Randomized controlled trial of postoperative radiotherapy and short-term timescheduled 5-fluorouracil against surgery alone in the treatment of Dukes B and C rectal cancer. Br J Surg 1997;84:1130-1135.

43 NIH Consensus Conference: Adjuvant therapy for patients with colon and rectal cancer. JAMA 1990;264:1444-1450.
44 Wolmark N, Wieand HS, Hyams DM, Colangelo L, Dimitrov NV, Romond EH, Wexler M, Prager D, Cruz AB Jr, Gordon PH, Petrelli NJ, Deutsch M, Mamounas E, Wickerham DL, Fisher ER, Rockette H, Fisher B: Randomized trial of postoperative adjuvant chemotherapy with or without radiotherapy for carcinoma of the rectum: National Surgical Adjuvant Breast and Bowel Project Protocol R-02. J Natl Cancer Inst 2000;92:388-396.

45 O'Connell MJ, Martenson JA, Wieand HS, Krook JE, Macdonald JS, Haller DG, Mayer RJ, Gunderson LL, Rich TA: Improving adjuvant therapy for rectal cancer by combining protracted infusion fluorouracil with radiation therapy after curative surgery. N Engl J Med 1994;331:502-507.

46 Mansour EG, Lefkopoulou M, Johnson R, Douglass $\mathrm{H}$ : A comparison of postoperative adjuvant chemotherapy, radiotherapy or combination therapy in potentially curable resectable rectal carcinoma. An ECOG study Es 4276 (abstract). Proc Am Soc Clin Oncol 1991; 10:154.

47 Fountzilas G, Zisiadis A, Dafni U, Konstantataras $\mathrm{C}$, Hatzitheoharis $\mathrm{G}$, Liaros A, Athánassiou E, Dombros N, Dervenis C, Basdanis G, Gamvros O, Souparis A, Briasoulis E, Samantas E, Kappas A, Kosmidis P, Skarlos D, Pavlidis N: Postoperative radiation and concomitant bolus fluorouracil with or without additional chemotherapy with fluorouracil and high-dose leucovorin in patients with high-risk rectal cancer: A randomized phase III study conducted by the Hellenic Cooperative Oncology Group. Ann Oncol 1999;10:671-676.

48 Tepper JE, O'Connell MJ, Petroni GR, Hollis D, Cooke E, Benson AB III, Cummings B, Gunderson LL, Macdonald JS, Martenson JA: Adjuvant postoperative fluorouracil-modulated chemotherapy combined with pelvic radiation therapy for rectal cancer: Initial results of intergroup 0114. J Clin Oncol 1997;15: 2030-2039.

49 Bakkevold KE, Arnesjö B, Dahl O, Kambestad B: Adjuvant combination chemotherapy (AMF) following radical resection of carcinoma of the pancreas and papilla of Vater results of a controlled, prospective, randomized multicenter study. Eur J Cancer 1993; 29A:698-703.

50 Amano H, Takada T, Kato H, Matsushiro T, Nimura Y, Nagakawa T, Nakayama T, Gomi $\mathrm{K}$ : Five-year results of a randomized study of postoperative adjuvant chemotherapy for resected pancreatic-biliary carcinomas. Proc Am Soc Clin Oncol 1999; 18:abstract 1049.

51 Kalser MH, Ellenberg SS: Pancreatic cancer: Adjuvant combined radiation and chemotherapy following curative resection of pancreatic cancer. Cancer 1985;120:899-903.

52 Klinkenbijl JH, Jeekel J, Sahmoud T, van Pel $\mathrm{R}$, Couvreur ML, Veenhof $\mathrm{CH}$, Arnaud JP, Gonzalez DG, de Wit LT, Hennipman A, Wils $\mathrm{J}$ : Adjuvant radiotherapy and 5-fluorouracil after curative resection of cancer of the pancreas and periampullary region: Phase III trial of the EORTC gastrointestinal tract cancer cooperative group. Ann Surg 1999;230:776-782. 
53 Neoptolemos JP, Dunn JA, Stocken DD, Almond J, Link K, Beger H, Bassi C, Falconi M, Pederzoli P, Dervenis C, Fernandez-Cruz L, Lacaine F, Pap A, Spooner D, Kerr DJ, Friess H, Büchler MW: Adjuvant chemoradiotherapy and chemotherapy in resectable pancreatic cancer: A randomised controlled trial. Lancet 2001;358:1576-1585.

54 Gastrointestinal Tumor Study Group: Further evidence of effective adjuvant combined radiation and chemotherapy following curative resection for pancreatic cancer. Cancer 1987;59: 2006-2010.

55 Moertel CG, Frytak S, Hahn RG, O’Connell MJ, Reitemeier RJ, Rubin J, Schutt AJ, Weiland LH, Childs DS, Holbrook MA, Lavin PT, Livstone E, Spiro H, Knowlton A, Kalser M, Barkin J, Lessner H, Mann-Kaplan R, Ramming K, Douglas HO Jr, Thomas P, Nave H, Bateman J, Lokich J, Brooks J, Chaffey J, Corson JM, Zamcheck N, Novak JW: Therapy of locally unresectable pancreatic carcinoma: A randomized comparison of high dose $(6000$ rads) radiation alone, moderate dose radiation (4000 rads + 5-fluorouracil), and high dose radiation + 5-fluorouracil: The Gastrointestinal Tumor Study Group. Cancer 1981;48: 1705-1710.

56 Gastrointestinal Tumor Study Group: Treatment of locally unresectable carcinoma of the pancreas: Comparison of combined-modality therapy (chemotherapy plus radiotherapy) to chemotherapy alone. J Natl Cancer Inst 1988 80:751-755.

57 Gastrointestinal Tumor Study Group: Radiation therapy combined with adriamycin or 5fluorouracil for the treatment of locally unresectable pancreatic carcinoma. Cancer 1985 $56: 2563-2568$.

58 Janunger K, Hafström L, Nygren P, Glimelius $\mathrm{B}$ : A systematic overview of chemotherapy effects in gastric cancer. Acta Oncol 2001;40: 309-326.
59 Holbrook MA: Cancer of the gastrointestinal tract: Radiation therapy. JAMA 1974;228: 1289-1290.

60 Schein PS, Novak J: A comparison of combination chemotherapy and combined modality therapy for locally advanced gastric carcinoma. Cancer 1982;49:1771.

61 Schein PS, Smith FP, Woolley PV, Ahlgren JD: Current management of advanced and locally unresectable gastric carcinoma. Cancer 1982; 50:2590-2596.

62 Bleiberg H, Goffin JC, Dalesio O, Buyse M, Pector JC, Gignoux M, Roussel A, Samana G, Michel J, Gerard A: Adjuvant radiotherapy and chemotherapy in resectable gastric cancer. A randomized trial of the gastrointestinal tract cancer cooperative group of the EORTC. Eur J Surg Oncol 1989;15:535-543.

63 MacDonald JS, Smalley SR, Benedetti J, Hundahl SA, Estes NC, Stemmermann GN, Haller DG, Ajani JA, Gunderson LL, Jessup JM, Martenson JA: Chemoradiotherapy after surgery compared with surgery alone for adenocarcinoma of the stomach or gastroesophageal junction. N Engl J Med 2001;345:725-730.

64 Permert J, Hafström L, Nygren P, Glimelius B: A systematic overview of chemotherapy effects in pancreatic cancer. Acta Oncol 2001;40:361370.

65 Goggins M, Kern SE, Offerhans JA, Hruban $\mathrm{RH}$ : Progress in cancer genetics. Lessons from pancreatic cancer. Ann Oncol 1999;10(suppl 4):S4-S8.

66 Frykholm-Jansson G, Isacsson U, Sintorn K, Montelius A, Jung B, Påhlman L, Glimelius B: Preoperative radiotherapy in rectal carcinoma - aspects of adverse effects and radiation technique. Int J Radiat Oncol Biol Phys 1996;35: 1039-1048.

67 Fahlke J, Ridwelski K, Meyer F: Immunohistochemistry of lymph nodes in pancreatic carcinoma. Proc ECCO 11, Lisbon, 2001, abstract 58.
68 Kapiteijn E, Marijnen CAM, Nagtegaal ID, Putter H, Steup WH, Wiggers T, Rutten HJT, Leer JWH, van Krieken JHJM, Påhlman L, Glimelius B, van de Velde CJH: Preoperative radiotherapy in combination with total mesorectal excision improves local control in resectable rectal cancer. Report from a multicenter randomized trial. For the Dutch Colo Rectal Cancer Group and other cooperative investigators. N Engl J Med 2001;345:638-646.

69 Glimelius B: Pre- or postoperative radiotherapy in rectal cancer - more to learn? Radiother Oncol 2001;61:1-5.

70 Glimelius B, Isacsson U: Preoperative radiotherapy for rectal cancer - is $5 \times 5$ Gy a good or a bad schedule? Acta Oncol 2001;40:958967.

71 Smalley SR, Gunderson L, Tepper J, Martenson JA, Minsky BD, Willett C, Rich T: Gastric surgical adjuvant radiotherapy consensus report: Rationale and treatment implementation. Int J Radiat Oncol Biol Phys 2002;52:283293.

72 Schrag D, Gelfand SE, Bach PB, Guillem J, Minsky BD, Begg CB: Who gets adjuvant treatment for stage II and III rectal cancer? Insight from surveillance, epidemiology, and end results - Medicare. J Clin Oncol 2001;19:37123718 .

73 Bujko K, Nowacki M, Oledzki J, Sopylo R, Skoczylas J, Chwalinsky M: Sphincter preservation after short-term preoperative radiotherapy for low rectal cancer. Presentation of own data and a literature review. Acta Oncol 2001; 40:593-601.

74 Miller RC, Martenson JA, Sargent DJ, Kahn MJ, Krook JE: Acute treatment-related diarrhea during postoperative adjuvant therapy for high-risk rectal carcinoma. Int J Radiat Oncol Biol Phys 1998;41:593-598.

75 Cafiero F, Gipponi M, Peressini A, Bertoglio S, Lionetto R: Preliminary analysis of a randomized clinical trial of adjuvant postoperative RT vs. postoperative RT plus 5-FU and levamisole in patients with TNM stage II-III resectable rectal cancer. J Surg Oncol 2000;75:80-88. 